UDK 630*6:630*43(497.6 Prozor-Rama)

$630 * 43: 630 * 6(497.6$ Prozor-Rama)

\title{
TOTAL ECONOMIC VALUATION OF THE DAMAGES FROM FOREST FIRES: CASE STUDY PROZOR-RAMA MUNICIPALITY
}

\section{Sveukupno vrednovanje šteta od šumskih požara: studij slučaja općina Prozor- Rama}

Sabina Delić ${ }^{1}$, Dženan Bećirović ${ }^{1}$, Vedrana Jurić ${ }^{2}$, Senka Mutabdžija ${ }^{1}$, Bruno Marić $^{1}$, Osman Mujezinović ${ }^{1}$, Stjepan Kvesić ${ }^{3}$, Mersudin Avdibegović ${ }^{1}$

\begin{abstract}
Despite of the significant activities on the forest fires prevention, number of forest fires is constantly growing worldwide causing tremendous direct and indirect damages. Direct damages are referring to the losses on timber and other forest products, fire fighting and remediation costs as well as costs of fire sites restoration. Indirect damages are referring to the negative impacts of forest fires on various ecosystem services and overall conditions of environment. Despite of the fact that indirect damages could be far greater than direct ones, in most of the cases in BosniaHerzegovina, they are not included in the assessment of the damages and methodology for their calculation is not developed yet.

The goal of this paper is to conduct the economic valorisation of direct and indirect damages from forest fires at the territory of Prozor-Rama municipality in 10-years period in which the scope and frequency of the forest fires were determined. The methodology that is used in this paper is developed by European experts on assessment of socio-economic damages from forest fires in Europe (PETTENELLA et al, 2008). Formula for calculation of damages of some functions and values of forests are partially modified due to the specific conditions of forest management practice and characteristics of forest stands, while some of them were excluded from assessment since they required additional research for their valuation. Calculated values of the damages are 11 times greater than those that are presented in the Register of the damages from forest fires of the Public Forest Enterprise „Šume Herceg-Bosne“. Modified method could be a sound basis for development of methodology for assessment of the damages from forest fires and total economic valuation of forest ecosystems in Bosnia-Herzegovina.
\end{abstract}

\footnotetext{
${ }^{1}$ Faculty of Forestry, University of Sarajevo

2 MSc of forestry, Varvara 100, Rama - Prozor 88440

3 PFE ,Šume Središnje Bosne” Ltd.
} 
Key words: forest fires, direct and indirect damages, method of total economic valuation of damages from forest fires.

\section{INTRODUCTION - Uvod}

Forest fires represent the biggest threat to the forest ecosystems whose consequences, very often, acquire catastrophic proportions. They are causing almost immediate vanish of a huge complex of forests which lead to the severe changes in landscapes. Out of rich and stabile forest ecosystems they are making fire scenes and bare lands while forest enterprises suffer a huge financial consequences and serious business-disruptions that are, very often, almost impossible to correct. Negative ecological consequences of the forest fires are well beyond of their perception right after the forest fires. They can be partially assessed through application of certain coefficients (UsČUPLIĆ, 2001).

Average area annually covered by fire throughout Europe is more than half a million hectares, of which 95\% occur in Mediterranean countries (Portugal, Spain, France, Italy, and Greece). During 2012 in these 5 countries forest fires burned a total area of 519424 ha, that is well above the average of the last 20 years (JRC TECHNICAL REPORT, 2012). Assessment of the socio-economic damages from forest fires is of great importance, but at the same time it is difficult to conduct due to the multifunctional character of the forest resources and losses of different types of forest products and services, particularly non-market ones (MAVSAR, 2011). Comprehensive assessment of ecological and socio-economic damages from forest fires have an important role in defining instruments of forest policy and their consistent implementation in prevention of forest fires. Due to the fact that causes and spatial distribution of forest fires differ in different regions and countries, activities on prevention and combat with forest fires need to be harmonized with socio-economic characteristics of specific area (MONTIEL, 2010). Therefore, it is worthwhile to mention that around $95 \%$ of the all forest fires in Europe are caused by anthropogenic factor (CANTRY, 2010). This is the fact that should be taken into consideration during the definition of measures for forest fires prevention.

The goal of this paper is to conduct the economic valorisation of direct and indirect damages from forest fires at the territory of Prozor-Rama municipality in 10years period in which the scope and frequency of the forest fires were determined.

\section{MATERIALS AND RESEARCH METHODS - Materijal i metode istraživanja}

Territory of Prozor-Rama municipality represents the research area of this paper. This municipality is located at the northern part of Herzegovina. Forests and forest land cover 26.867 ha, out of which $91 \%$ of the forests are owned by the State 
while $9 \%$ are privately owned. The structure of the forest stands is quite unfavourable: $21,5 \%$ are high forests, 7,6\% are high degraded forests, $2,4 \%$ planted forests, $25,5 \%$ coppice forests and $43 \%$ barren lands. Based on the risk assessment from forest fires, around $35 \%$ of the forest and forest land that are managed by forest enterprise "Rama" belongs to the area with significant and very significant threat. Mixed stands of planted forests, mixed beech, fir and spruce stands and degraded stands of heliophilous broadleaves belong to this category. Other forests (stands of broadleaves sciophytes and barren forest lands) belong to the area of moderate risks (PLAN FOR PROTECTION FROM FOREST FIRES, 2011).

Information from the period 2002-2011 that were used for the analysis conducted for the purpose of this paper are as follows: number, types, seasonal dynamics, causes and fluctuation of forest fires and size of the forests and forest land burned by the fire. These information were taken from Register of forest fires of the Public Forest Enterprise „Šume Herceg-Bosne“, Forest Management Unit „Rama“ and departure of Cantonal forest office in Prozor-Rama. Values of direct damages from forest fires were taken from same sources. The study entitled as: Proposal for a Harmonized Methodology to assess socio-economic damages from forest fires in Europe (PETTENELLA et al, 2008) were taken as a basis for the method that was created for the purpose of this paper.

Identification of socio-economic and ecological components is the first step of implementation of this analysis. Second step is referring to the assessment of the damages from forest fires for all of the identified components. In case of this method, damages from forest fires can be assessed on two ways: rapid and analytical. Rapid approach is based upon reconstruction costs and coefficient of damages from forest fires with application of discount rate and number of years for forest recovering. This is the less-detailed approach and it gives smaller values than analytical one. Analytical approach is based on single function assessment. It takes into consideration both direct and indirect uses of forest ecosystems. The first essentially concerns goods such as timber, non wood forest products, firewood, grazing, hunting and services that provide private benefits such as recreational tourism. The value of indirect use concerns environmental functions carried out by a forest such as hydrogeological protection, water cycle regulation, biodiversity conservation and fixation of atmospheric carbon (Pettenella et al, 2008). For all of these functions, different assessment criteria are taken into consideration (Picture 1) while sum of their values represent total economic value of the damages.

Based on the functions and criteria presented at the Picture 1, formulas for calculation of damages for all functions were created. For the purpose of this paper, formulas had been modified and adjusted to forest management practice in the Federation of Bosnia-Herzegovina. These calculations did not include all of the functions that have been suggested in the Proposal for a harmonized methodology to assess socioeconomic damages from forest fires in Europe (PETTENELLA et al, 2008). Based on the situation on certain area, assessment procedure should include different 
functions of forest ecosystems that are, very often, neglected in various assessments. Furthermore, it is unlikely that a fire will cause significant damage to all forest functions at the same time (PETTENELLA et al, 2008). Therefore, the valuation should be directed toward assessment of the most damaged functions in specific forest area.

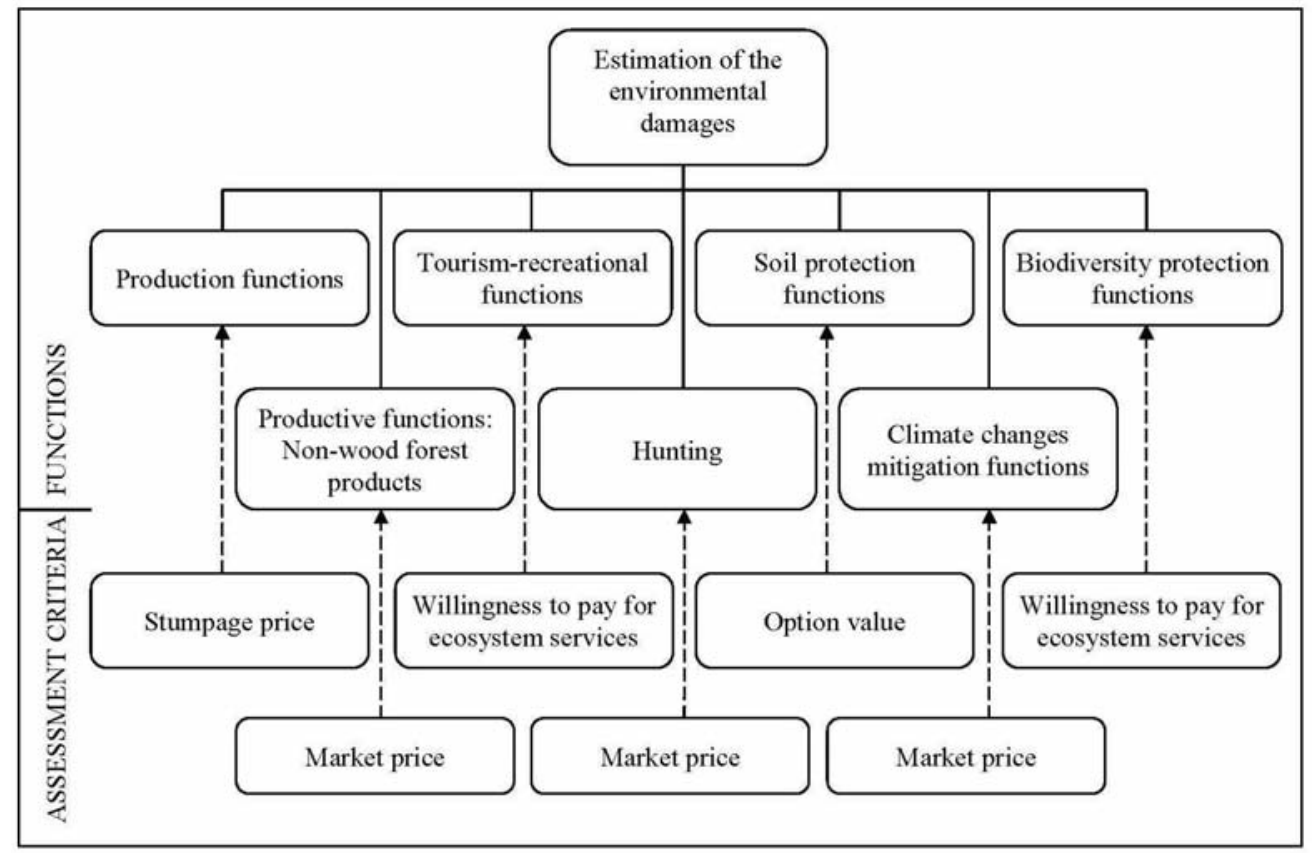

Picture 1: Functions and criteria for analytical assessment Slika 1: Funkcije i kriteriji za analitičku procjenu

Source: Modified according to Pettenella ET AL, 2008

Assessment of damages to productive, game management, soil protection and carbon dioxide sequestration functions was conducted in this paper. When it comes to the productive function, calculations were conducted separately for high, coppice forests and planted forests together with calculations for losses in non-wood forest products.

This approach represents a complex process of objective assessments and valorisations of all damages from forest fires. Assessment is conducted on the basis of the pre-defined functions of forest ecosystems and listed criteria. Sum of the values for separate components represents the total value of the direct and indirect damages from forest fires. 


\section{Productive function - Proizvodna funkcija}

a) High forests, coppice forests and planted forests - Visoke šume, izdanačke šume i šumske kulture

Damages on timber production caused by forest fires are more complex than simple loss of timber volume. Therefore, these damages should be perceived on comprehensive manner. It means that losses in annual increment and annual income that is gained from realized annual allowable cut should not be neglected.

Losses of productive functions are assessed separately for high forests, coppice forest and planted forests burned by fire. Suggested formulas from Proposal for a harmonized methodology to assess socioeconomic damages from forest fires in Europe (PetTEnella et al, 2008) were modified and adopted to specific forest management practice in Bosnia-Herzegovina. For the purpose of assessment of the damages from forest fires on productive functions of high forests from specific locality, following modified formula was used:

$$
E D_{t e}=F B A \times V o l \times\left(P_{i m p}-C_{t e}\right)+\left[E \times\left(P_{i m p}-C_{t e}\right) \times \frac{(1+r)^{m}-1}{r \times(1+r)^{m}}\right]
$$

Where:

$E D_{\text {te }}=$ environmental damage due to wood-producing loss (KM);

$F B A=$ forest area burned by the fire ( $h a)$;

$\mathrm{Vol}=$ volume of wood lost following the fire $\left(\mathrm{m}^{3} / \mathrm{ha}\right)$;

$E=$ annual allowable cut which is annually lost in the " $m$ " years period $\left(m^{3}\right)$;

$P_{\text {imp }}=$ mean roundwood price at roadside $\left(\mathrm{KM} / \mathrm{m}^{3}\right)$;

$C_{t e}=$ felling and logging costs $\left(\mathrm{KM} / \mathrm{m}^{3}\right)$;

$r=$ discount rate;

$m=$ years needed for newly established forest to reach equal amount of income as forest burned by fire

b) Non-wood forest products - Nedrvni šumski proizvodi

Due to the long-term consequences of forest fires, damages of non-timber forest product should be assessed as discounted annual losses of the total income. Therefore, this damage can be calculated by the following formula:

$$
E D_{N W F P}=F B A_{N W F P} \times R_{N W F P} \times \frac{(1+r)^{p}-1}{r \times(1+r)^{p}}
$$

Where:

$E D_{N W F P}=$ environmental damage from the loss of non-wood forest products (KM); 
$F B A_{N W F P}=$ area that produces non-wood products burned by the fire (ha); $R_{N W F P}=$ mean annual income from non-wood forest products (KM ha); $r=$ discount rate; $p=$ years of lost harvests of non-wood products following the fire.

Damages on game management - Vrijednost šteta u lovnom gospodarstvu

A criterion for assessment of damages on this basis is similar as for non-wood forest products. This means that overall environmental damage is calculated as a sum of annual damages for the period in which is impossible to carry out activities of game management and hunting. Such calculation is conducted with the following formula:

$$
E D_{h u n}=F B A_{h u n} \times R_{h u n} \times \frac{(1+r)^{v}-1}{r \times(1+r)^{v}}
$$

Where:

$E D_{\text {hun }}=$ environmental damage from decreased (KM);

$F B A_{\text {hnu }}=$ area used for hunting burned by the fire (ha);

$R_{\text {hun }}=$ mean annual income from hunting $(\mathrm{KM} / \mathrm{ha})$;

$r=$ discount rate;

$v=y e a r s$ of lost hunting activity following the fire.

\section{Assessment of the soil damages (effects on catchment areas and prevention from erosion) - Vrijednost šteta uslijed uništavanja tla (regulacija vodnog režima i sprečavanje erozije)}

In order to assess soil protection function, proposed approach is based upon criteria of replacement costs and fixed costs of vegetation regeneration of the fire sites. Costs of vegetation regeneration are consisted out of two components: onetime investment costs of establishment of new stands and costs of silvicultural activities for their maintenance that should be conducted in the upcoming period in order to assure protection function which this fire sites had before fire destruction. This can be calculated based on the following formula:

$$
E D_{\text {prot }}=F B A_{p r o t} \times\left(C_{r e v} \times r+C_{a n n} \times \frac{(1+r)^{i}-1}{r \times(1+r)^{i}}\right)
$$

Where:

$E D_{\text {prot }}=$ environmental damage from the decreased water cycle regulation and soil protection (KM);

FBAprot $=$ area with protective functions burned by the fire (ha);

Crev = cost of re-vegetation $(K M / h a)$; 
Cann = annual maintenance costs of the re-vegetation area $(\mathrm{KM} / \mathrm{ha})$;

$r=$ discount rate,

$i=$ years needed to maintain the area.

\section{Carbon dioxide sequestration function - Vrijednost vezivanja ugljika}

Formula for the calculation of this type of damages is based upon losses of woody biomass burned by fire, coefficient of transformation by volume of aboveground woody biomass ${ }^{5}$ and market price of the carbon ${ }^{6}$ :

$$
E D_{c}=F B A \times \operatorname{Vol}_{b} \times B E F \times 0,5 \times P_{c}
$$

Where:

$E D c=$ environmental damage from carbon emitted into the atmosphere (KM);

$F B A=$ forest area burned by the fire (ha);

$V o l b=$ volume of the above-ground woody biomass burned by the fire $\left(\mathrm{m}^{3} / \mathrm{ha}\right)$;

$B E F=$ Biomass Expansion Factor (coefficient of transformation by volume of the above-ground woody biomass, expressed in $\mathrm{m}^{3}$, into total biomass, expressed in $t$ of dry matter);

$0.5=1$ ton of dry timber has $50 \%$ of carbon;

$P_{c}=$ price of one ton of carbon $(K M / t)$

Damages of touristic-recreational function and biodiversity protection function were not taken into consideration since it is necessary to conduct separate research for their calculation by applying Contingent Valuation or Travel Cost Method (BISHOP, 1999).

\section{RESULTS AND DISCUSSION - Rezultati i diskusija}

Analysis of the forest fires at the territory of Prozor - Rama municipality in the period 2002 - 2011 - Analiza požara na području općine Prozor - Rama u periodu 2002 - 2011. godine

In the analysed period at the territory of Prozor-Rama municipality, 61 forest fires were recorded. What is more, only in year 2011, 27 forest fires (or 44\% of all recorded forest fires) had occurred (JURIĆ, 2012). Like in the other Mediterranean countries, there are two maximums of the forest fires appearance - spring when $41 \%$ of the forest fires occur and summer when the temperatures are on its peak, droughts could last for

\footnotetext{
${ }^{5}$ Coefficient of transformation is adopted from Pettenella et al, 2008.

${ }^{6}$ Market price of the carbon varies. It depends on the economic trends and its future predictions are various. Average price from 2006 according to EU-ETS were used for the purpose of this calculation.
} 
more than a month and people spend most of the time in nature. Onward, 93,5\% of all forest fires are caused by human activities such as springtime cleaning of the meadows, intentional burnings, reckless activities of tourists and vacationers etc. The biggest percentage $(65 \%)$ of all forest fires are caused by springtime cleaning of the meadows. Other researchers presented similar results for the occasions in BosniaHerzegovina (USČUPLIĆ, 2001). Furthermore, 95\% of the forest fires in Europe are caused by human activities, whether directly or indirectly (REGO, 2010).

Annual fluctuations (number of the forest fires and size of the fire sites) at the territory of Prozor-Rama municipality are presented at the Figure 1. From this Figure can be concluded that the size of the fire sites is not directly dependent on the number of the forest fires. It is due to the fact that a few stronger forest fires could destroy bigger forest areas than great number of forest fires with lower intensity.

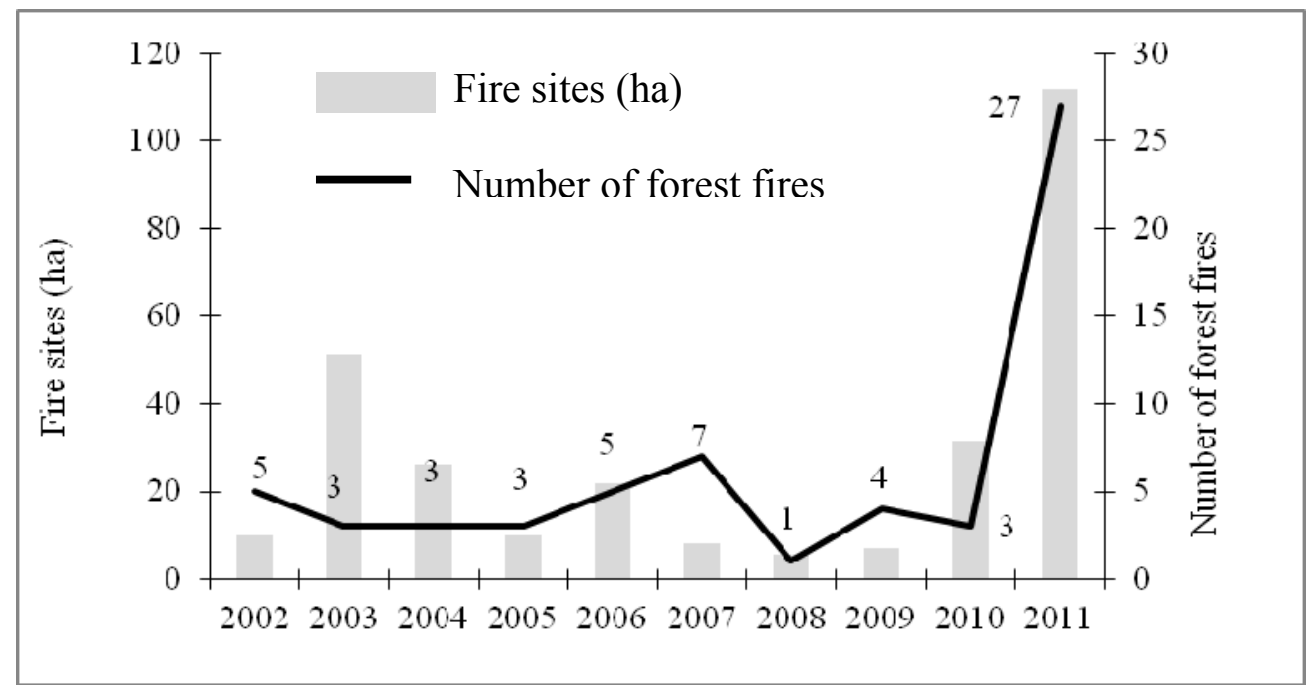

Figure 1: Fluctuation of the forest fires in Prozor-Rama municipality in the period 2002-2011 (Source: Register of forest fires (2002-2009), PFE "Šume Hercegovačko-neretvanske", Forest Management Unit „Rama“)

Grafikon 1: Fluktuacija šumskih požara u općini Prozor-Rama za period 2002-2011. godina (Izvor:Registar šumskih požara (2002-2009) Javnog poduzeća „Šume Herceg-Bosne“, Šumarije ,Rama“ “ U Uprave za šumarstvo - odjel Prozor-Rama)

In total, 12,5 ha of planted forests, 8,2 ha of high forests and 262,9 ha of coppice forests were burnt at the research area in the analysed period (Figure 2). The increasing area of fire sites indicates the severity of the problem. Most of the registered forest fires in this period are ground fires (around 69\%) while low and high fires were more frequent in the period 2002-2004 and in the years 2008 and 2011. 


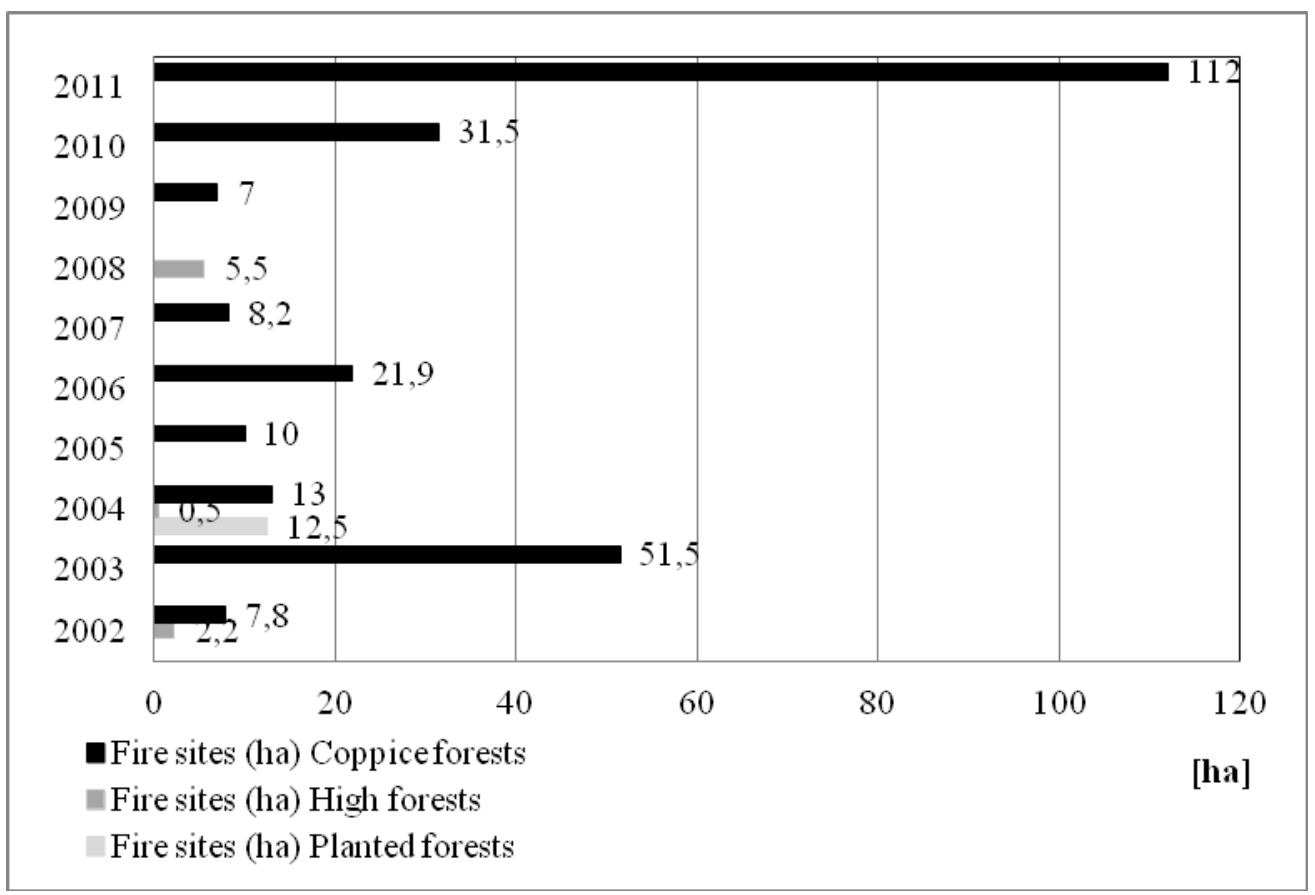

Figure 2: Size of fire sites in municipality Prozor-Rama for period 2002-2011 (Source: Register of forest fires (2002-2009), PFE "Šume Hercegovačko-neretvanske", Forest Management Unit „Rama“)

Grafikon 2: Opožarene površine u općini Prozor-Rama u periodu 2002- 2011. godina (Izvor:Registar šumskih požara (2002-2009) Javnog poduzeća „Šume Herceg-Bosne“, Šumarije „Rama“ $i$ Uprave za šumarstvo-odjel Prozor-Rama)

\section{Assessment of the damages from forest fires - Vrednovanje šteta od šumskih požara}

Due to the fact that forest fires are very frequent in Bosnia-Herzegovina and with devastating character, there is a need for the assessment of the damages caused by them. Forest fires are causing several direct as well as various indirect damages. Direct damages are referring to the losses of timber volume, undergrowth vegetation, non-wood forest products as well as fire fighting costs and costs of fire sites restoration. Indirect damages are referring to all types of habitat changes and losses of social and ecological functions of forest ecosystems. These types of damages are much higher than direct ones, albeit they have not been properly assessed in our country yet. Furthermore, there is no rulebook or agreed methodology for overall assessment of damages from forest fires in our forest management practice. Therefore, many domestic authors have been emphasizing a need for such assessment. Despite of the assessment of direct damages, there is a need for assessing the indirect damages 
that are very often only roughly estimated (UsčuPLIĆ, 2001). This author had suggested that assessment of damages from forest fires should be conducted through valorisation of the forest stands, type of forest protection and specific terrain characteristics. At the end, each fire site is rated with certain grades. The final grade represents coefficient of social and ecological functions of the fire site which is associated with direct damages.

Due to the lack of methodology for total valuation of forest functions in Bosnia-Herzegovina, damages of forest fires cannot be properly assessed (DELIĆ, 2003, 2011, 2012). Application of combined method for valorisation of forest ecosystem functions in one forest management unit had showed that social and ecological functions make 73\% while productive functions (value of timber volume, land property and facilities) make $27 \%$ of the total value of analyzed forest management unit (DELIĆ, 2003). In the process of choosing the most appropriate method to assess value of forest ecosystems, it is necessary to seek for the most realistic assessment method by using the methods that are applied worldwide and, at the same time, by respecting the specificities of forest management practice in BosniaHerzegovina.

Models for valuation of social and ecological functions of forest ecosystem have been developed in Croatia (RULE BOOK FOR FOREST MANAGEMENT PLANNING IN CROATIA, 2008). This methodology prescribes that each type of social and ecological functions should be evaluated according to the pre-defined types of social and ecological functions of forest ecosystems. Range of these rates depends on the type of forest stands such as forests managed for economic purposes, protective forests or special purpose forests (water protection, soil protection etc.). According to each type of social or ecological forest functions, certain rates are given to each of the categories of forest stands that can be monetary expressed (RULE BOOK FOR, 2008).

\section{Assessment of the direct damages from forest fires at the territory of Prozor-Rama municipality - Procjena direktnih šteta od požara na području općine Prozor-Rama}

Total amount of direct damages from forest fires at the territory of ProzorRama municipality in the analyzed period is $151.865 \mathrm{KM}$ (Table 1). Reported value is based upon productive functions of fire sites, whereby damages of timber volume amount $144.548 \mathrm{KM}$ while costs of fire fighting amounts $7.317 \mathrm{KM}$. The analysis showed that costs of fire fighting were not registered for all forest fires. However, costs of fire sites restoration were excluded from this assessment despite of the fact that they were indicated in the prescribed forms of this Register. This means that assessed damages that are presented in the Register do not include all losses of the benefits from forest ecosystems. Reason for such situation is, inter alia, unequal criteria for calculation of fire sites reforestation costs as well as costs of fire fighting that belongs to the group direct damages from forest fires. Costs of fire sites restoration to the state before fire, reduced fertility of the land for certain period of 
time or its total destruction from erosion, losses of timber volume etc. represents a severe financial loss which is not included in the registered damages (JURIĆ, 2012). Previously stated facts represent one of the main reasons for creation of the methodology for overall assessment of the damages from forest fires at the analyzed territory as well as for entire Bosnia-Herzegovina.

Table 1: Overall direct damages from forest fires in Prozor-Rama municipality in period 2002-2011 Tabela 1: Ukupna direktna šteta od požara u općini Prozor-Rama u periodu 2002-2011. godina

\begin{tabular}{|c|c|c|c|c|}
\hline Year & $\mathbf{2 0 0 2 - 2 0 0 9}$ & $\mathbf{2 0 1 0}$ & $\mathbf{2 0 1 1}$ & TOTAL (KM) \\
\hline $\begin{array}{c}\text { Value of the damage on fire sites } \\
\text { (KM) }\end{array}$ & 127.963 & 9.625 & 6.960 & $\mathbf{1 4 4 . 5 4 8}$ \\
\hline $\begin{array}{c}\text { Costs of fire fighting (KM) } \\
\text { Costs of fire sites restoration (KM) }\end{array}$ & 4.517 & 350 & 2.450 & $\mathbf{7 . 3 1 7}$ \\
\hline Total direct damages (KM) & 132.480 & 9.975 & 9.410 & $\mathbf{1 5 1 . 8 6 5}$ \\
\hline
\end{tabular}

Source: Register of forest fires of the Public Forest Enterprise „Šme Herceg-Bosne“, Forest Management Unit ,Rama" and departure of Cantonal forest office in Prozor-Rama (1KM= $0,51 \epsilon)$

Total economic valuation of the damages from forest fires according to the analytical approach - Ukupna vrijednost šteta od požara prema analitičkom pristupu

According to analytical approach, overall value of the damages from forest fires at the territory of Prozor-Rama municipality in the analysed period was 1.731.023 KM (Table 2). Assessment of touristic-recreational and biodiversity protection function were not taken into consideration in these calculations. Productive function of the forest ecosystems (timber and non-timber forest products) represents $39 \%$ of the total value of the damages that are calculated according to analytical approach. Despite of the potential for game management, this function is not implemented at the territory of the Prozor-Rama municipality, yet and assessment of the losses in game management showed relatively small value $(0,1 \%$ of total value of damages from forest fires). Damages of carbon dioxide sequestration function makes $12 \%$ of the overall assessment of the damages from forest fires while the biggest share (49\%) belongs to the soil protection function (effects on catchment areas and prevention from erosion). Such high share is reasonable due to the fact that this function is nowadays perceived as one of the most important functions of forest ecosystems. 
Table 2: The analytical approach based on total valuation of forest functions

Tabela 2. Analitički pristup baziran na procjeni pojedinačnih funkcija šuma

\begin{tabular}{|c|c|c|c|c|}
\hline \multicolumn{4}{|c|}{ Analytical approach } & Total (KM) \\
\hline \multirow{3}{*}{$\begin{array}{l}\text { Productive } \\
\text { products }\end{array}$} & \multirow{3}{*}{ function: timber } & High forests & $197.974 \mathrm{KM}$ & \multirow{3}{*}{669.832} \\
\hline & & Coppice forests & $462.220 \mathrm{KM}$ & \\
\hline & & Planted forests & $9.638 \mathrm{KM}$ & \\
\hline \multicolumn{4}{|c|}{ Productive function: non-timber forest products } & 575 \\
\hline \multicolumn{4}{|c|}{ Game management } & 1.768 \\
\hline \multicolumn{4}{|c|}{ Soil protection function } & 848.622 \\
\hline \multicolumn{4}{|c|}{ Carbon sequestration } & 202.909 \\
\hline \multicolumn{4}{|c|}{ Fire fighting costs } & 7.317 \\
\hline \multicolumn{4}{|c|}{ TOTAL (KM) } & $\mathbf{1 . 7 3 1 . 0 2 3}$ \\
\hline
\end{tabular}

$(1 K M=0,51 €)$

\section{CONCLUSIONS - Zaključci}

Forest fires represent one of the most dangerous threats for natural and cultural assets of human kind. With population growth, industrial and economical development, threat from forest fires is increasing despite of the growing opportunities for their localisation and fire fighting efforts. Forest fires are frequent in BosniaHerzegovina while their number in Prozor-Rama municipality is constantly increasing. The most common reason for forest fire is anthropogenic factor (93,5\%). This is important information for planning and decision making regarding measures and activities on prevention and development of the strategy for forest protection.

Forest fires are causing severe damages. Therefore, there is a need for development of adequate methodology for assessment of overall damages caused by forest fires. Furthermore, there is no rulebook of agreed methodology for overall assessment of damages from forest fires in forest management practice in BosniaHerzegovina. Total value of the direct damages from forest fires, documented in the Register of the damages from forest fires at the territory of Prozor-Rama municipality is $151.865 \mathrm{KM}$ in the analyzed period. Due to the methodology of its calculation, assessed value from this Register does not include all damages caused by forest fires. Therefore, assessed value of the damages from forest fires is incomplete.

By applying the methodology for the assessment of socio-economic damages from forest fires in Europe, with certain modifications, calculated value of the damages from forest fires was 11 times greater than overall direct costs reported in the Register. This is comprehensive methodology that includes various parameters that are not evaluated (nor documented) in our forest management practice despite of the need for information about them.

In order to be able to assess damages from forest fires more realistically, it is necessary to develop methodology for their overall assessment. Modified methodology that was used for the purpose of this paper, together with its results, can 
be a good starting point for development of the methodology for assessment of the damages from forest fires as well as methodology for total economic valuation of forest functions in Bosnia-Herzegovina. Importance of economic valuation of environmental damages have been increasing for the last couple of years since it represents one of the most important elements for environmental protection and sustainable development.

\section{REFERENCES - Literatura}

BISHOP, J. T. (1999): Valuing Forests - A review of Methods and Application in Developing Countries, Environmental Economics Programme, IIED.

Catry, F. X, Rego, F. C., Silva, S. J., MoreiRA, F. (2010): Fire starts and Human Acivities, Towards Integrated Fire Management - Outcomes of the European Project Fire Paradox, Europen Forest Institute Research Report 23, 2010, Joensuu, Finland

DELIĆ, S. (2003): Sveukupno vrednovanje šuma, Radovi Šumarskog fakulteta, Broj 1.Knjiga XXXIII, Šumarski fakultet, str. 29-39, Sarajevo

DELIĆ, S., BEĆIROVIĆ, Dž. (2012): Značaj i potreba ukupnog ekonomskog vrednovanja šuma, Naučna konferencija "Šume - indikator kvaliteta okoliša", Zbornik radova, Posebna izdanja, Odjeljenje prirodnih i matematičkih nauka, Knjiga 19, Akademija nauka i umjetnosti Bosne i Hercegovine, Sarajevo, 2012.

Delić, S., Pozdarec, M. (2011): Vrijednost šuma i šumskog zemljišta, Studija, Završni izvještaj, Federalno ministarstvo poljoprivrede, vodoprivrede i šumarstva, Available at: www.fmpvs.gov.ba

JOINT TECHNICAL REPORTS (2012): Forest Fires in Europe, Middle East and North Africa in 2012, JRC and EU Directorate-General Environment, Available at: http://forest.jrc.ec.europa.eu

JURIĆ, V. (2012): Ekonomsko vrednovanje šteta od šumskih požara na području općine Prozor - Rama, Završni rad II ciklusa studija, Šumarski fakultet Univerziteta u Sarajevu

Mavsar, R., Pettenella, D., San-Miguel, J. Camia, A. (2011): Development of methodology for the analysis of socio-economic impact of forest fires in Europe, The $5^{\text {th }}$ International Wildland Fire Conference Sun City, South Africa, Available at: www.wildfire2011.org

Montiel, C., Herrero, G. (2010): An Overview of Policies and Practices Related to Fire Ignitions at the European Union Level, Towards Integrated Fire Management - Outcomes of the European Project Fire Paradox, Europen Forest Institute Research Report 23, 2010, Joensuu, Finland

Pettenella, D., Marchetti, M., Marino, D., Marucc, A., Ottaviano, M., Lasserre, B. 
(2008): Proposal for a harmonized methodology to assess socio-economic damages from forest fires in europe, Italy, Available at: www.effis.jrc.ec.europa.eu

Plan for protection from forest fires (2011), PFE "Šume Hercegovačko-neretvanske", Ltd. Mostar

REGISTER OF FOREST FIRES (2002-2009), PFE "Šume Hercegovačko-neretvanske", Forest Management Unit „Rama“

REGISTER OF FOREST FIRES (2010-2011), Uprava za šumarstvo-odjel Prozor-Rama

Rego F., Rigolor, E., Fernandes, P., Montiel, C., Sande Silva, J. (2010): Towards Intergrated Fire Management, Efi Policy Brief 4, European Forest Institute, Joensuu, Finland

RULE BOOK FOR FOREST MANAGEMENT PLANNING IN CROATIA (2008): Official gazette, No.XX/08, Available at: www.zakon.poslovna.hr

UsčUPLIĆ, M. (2001): Šumski požari u Bosni i Hercegovini i evaluacija šteta, Radovi Šumarskog fakulteta Univerziteta u Sarajevu, No 1, 2001. (7-17)

\section{SAŽETAK}

Opasnost od nastajanja požara raste sa porastom stanovništva, industrijskim i privrednim razvojem te demografskim kretanjima, iako se povećava mogućnost njegovog lokaliziranja i gašenja. Broj požara na području općine Prozor-Rama u analiziranom periodu je u porastu, a osnovni uzrok nastanka požara je antropogeni faktor $(93,5 \%)$. Šumski požari sa sobom donose ogromne direktne i indirektne štete. Direktne štete obuhvaćaju gubitak drveta i ostalih proizvoda šume, troškove gašenja te troškove sanacije i rekultivacije požarišta, dok indirektne štete obuhvataju negativan uticaj požara na gubitak općekorisnih funkcija šuma i štete na okolišu. I pored toga što indirektne štete mogu biti daleko veće u odnosu na direktne, u našoj zemlji se one ne obračunavaju. Razlog tome je nedostatak propisane metodike njihovog obračuna.

Cilj ovog rada je ekonomsko vrednovanje šteta od šumskih požara na području općine Prozor-Rama pri čemu se nastojalo obuhvatiti što više obezvrijeđenih funkcija šume. Na osnovu analize broja, vrste šumskih požara, sezonske dinamike, uzroka, fluktuacije i opožarene površine u periodu od 10 godina došlo se do spoznaje o direktnim i indirektnim štetama koje nastaju od požara. U radu je za obračun šteta korištena metodika koja je razvijena od strane europskih stručnjaka za procjenu socioekonomskih šteta od šumskih požara u Evropi (PETTENELLA et al, 2008). Formule za obračun pojedinih komponenti su djelimično modificirane u skladu sa konkretnim uslovima, dok su neke komponente izostavljene zbog potrebe provođenja posebnih istraživanja za njihovu valorizaciju. Dobivene vrijednosti šteta od požara prema modificiranoj metodici su veće za oko 11 puta u poređenju sa iskazanim štetama u 
Registrima šumskih požara Javnog poduzeća „Šume Herceg-Bosne“, Šumarije „Rama“ i Uprave za šumarstvo - odjel Prozor-Rama.

U cilju realnijeg iskazivanja šteta od šumskih požara smatramo da je nužno pristupiti izradi metodike za sveobuhvatnu procjenu šteta od požara. Korištena modificirana metodika i rezultati njene primjene $u$ ovom radu bi mogli biti dobra osnova za razvoj metodike za obračun šteta od požara, kao i sveukupnog vrednovanja šumskih resursa u BiH. Posljednjih godina važnost ekonomskog vrednovanja šteta nanesenih okolišu je porasla, jer to predstavlja jedan od bitnih elemenata za zaštitu okoliša i održivi razvoj. 